\title{
Effectiveness of enzyme inhibitors in biomedicine and pharmacotherapy
}

\begin{abstract}
The enzyme inhibitors are low molecular weight chemical molecules, which can decrease or totally inhibit the enzyme catalytic activity either irreversibly or reversibly. Reversible competitive inhibitors bind non-covalently to the active site of the enzyme and compete with the substrate. Uncompetitive reversible inhibitors bind exclusively to the enzyme-substrate $(E S)$ complex or to subsequent enzyme forms. Noncompetitive reversible inhibitors bind to both the free enzyme and to the $E S$ complex or subsequent enzyme forms. The impact of enzyme inhibitors in drug discovery has become a fundamental approach to pharmacology at any pharmaceutical industry or drug research center. More than 100 enzyme inhibitors are currently marketed and double than those are under development. Such inhibitors exhibit their specific action in enzyme inhibition inside cells, bacteria, virus, and human body. They can be used for the treatment of various disorders and diseases including asthma and chronic obstructive pulmonary disease, cardiovascular diseases, erectile dysfunction, gastrointestinal disorders, hepatitis $\mathrm{B}$ virus infection, hepatitis $\mathrm{C}$ virus infection, herpes virus infections, human immunodeficiency virus (HIV)/acquired immune deficiency syndrome (AIDS) and rheumatoid arthritis and related inflammatory diseases.
\end{abstract}

Keywords: drug, inhibition, irreversible, competitive, non-competitive, uncompetitive, pharmaceutics
Volume 5 Issue 2 - 2019

\author{
Awatef Ouertani, Mohamed Neifar, Rania \\ Ouertani,Ahmed Saleheddine Masmoudi, \\ Amor Mosbah,Ameur Cherif \\ University of Manouba, Tunisia
}

Correspondence: Mohamed Neifar, LR Biotechnology and Bio-Geo Resources Valorization (LRI IES3 I), Higher Institute for Biotechnology, University of Manouba, Biotechpole of Sidi Thabet, 2020,Ariana,Tunisia, Tel 002167052788 2,

Email mohamed.naifar@gmail.com

Received: May 01, 2019 | Published: June 28, 2019

\section{Introduction to some basics of enzyme inhibition}

Enzymes are incredibly efficient biological catalysts that catalyze all cellular processes. ${ }^{1}$ However, several studies shed light on the importance of enzyme inhibitors in the pharmaceutical industry. ${ }^{2}$ The study of enzyme inhibitors has provided valuable information on the mechanisms of enzymatic action and has helped identify some metabolic pathways. Enzyme inhibitors are subdivided into two broad classes: reversible and irreversible (Figure 1). ${ }^{3}$

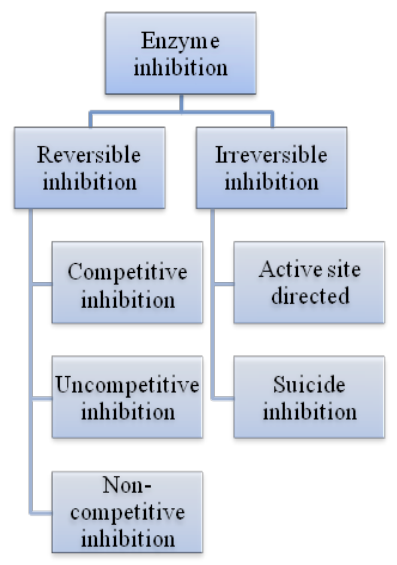

Figure I Enzyme inhibitors and classification of enzyme inhibition.

\section{Reversible inhibition}

For reversible inhibition, the inhibitors bind no covalently to enzyme leading to rapid full inhibition. Hence, reversible inhibitors can be simply removed by dilution to lower the concentration of the inhibitor or dialysis of the enzyme-inhibitor mixture. ${ }^{4}$ There are three types of reversible enzyme inhibition:

1. Compétitive inhibition,

2. Uncompetitive inhibition and

3. Mixed and non-competitive inhibition (Table 1).

Competitive inhibition: Reversible competitive inhibition is defined as a competition between the substrate and the inhibitor for the active site of an enzyme. The competitive inhibitor resembles the substrate, it occupies the active site of an enzyme and consequently prevents binding of the substrate. The complex enzyme- inhibitor don't lead to catalysis. ${ }^{5}$ Tan et al studied the mechanism of competitive inhibition of Jack Bean Urease by Baicalin (BA), the principal component of Radix Scutellaniae. The enzyme activity was determined by measuring the concentration of the ammonia released in the reaction mixture using spectrophotometric at $595 \mathrm{~nm}$. Results demonstrated that the inhibition of BA is reversible and competitive targeting thiol group in the active site of urease. Both reversibly and concentration dependently serving as a promising urease inhibitor for treatments in urease related disease. ${ }^{6}$ The sulfanilamide $\mathrm{C}_{6} \mathrm{H}_{8} \mathrm{~N}_{2} \mathrm{O}_{2} \mathrm{~S}$ (Figure 2) is an example of competitive inhibitor which is the simplest form of Sulfa drugs. It acts as antibacterial chemotherapeutic drug by competitive antagonism of p-aminobenzoic acid in the biosynthesis of folic acid. Due to the structural similarity between sulfonamides and p-aminobenzoic acid, they take its place in the active site of the enzyme dihydropteroate synthetase blocking the metabolic pathway, which results in the inability of the microorganism to synthesize nucleotides and other metabolites essential for growth. ${ }^{7,8}$ 


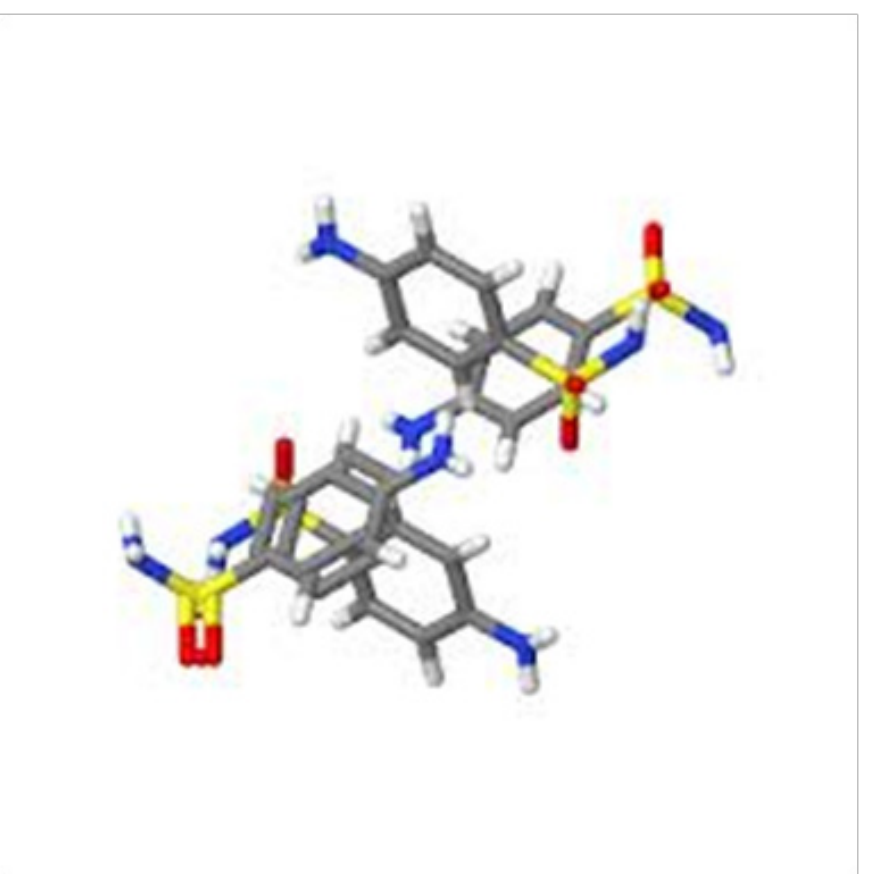

Figure 2 Crystal structure of Sulfanilamide $\left(\mathrm{C}_{6} \mathrm{H}_{8} \mathrm{~N}_{2} \mathrm{O}_{2} \mathrm{~S}\right)$ a competitive inhibitor. ${ }^{8}$

Uncompetitive inhibition: Uncompetitive inhibition necessitates the formation of enzyme-substrate complex. The inhibitor binds to the formed complex thus preventing the reaction of the enzyme with the substrate and the product formation. ${ }^{9}$ The no nucleoside reverse transcriptase inhibitors (NNRTIs) (Figure 3), used in the treatment of AIDS, provide interesting examples of clinically relevant uncompetitive inhibitors. ${ }^{10}$ Thus, antiretroviral-naive patients achieved good antiviral response after 48 weeks of treatment with potent highly active antiretroviral therapy regimens containing (NNRTIs). ${ }^{11}$

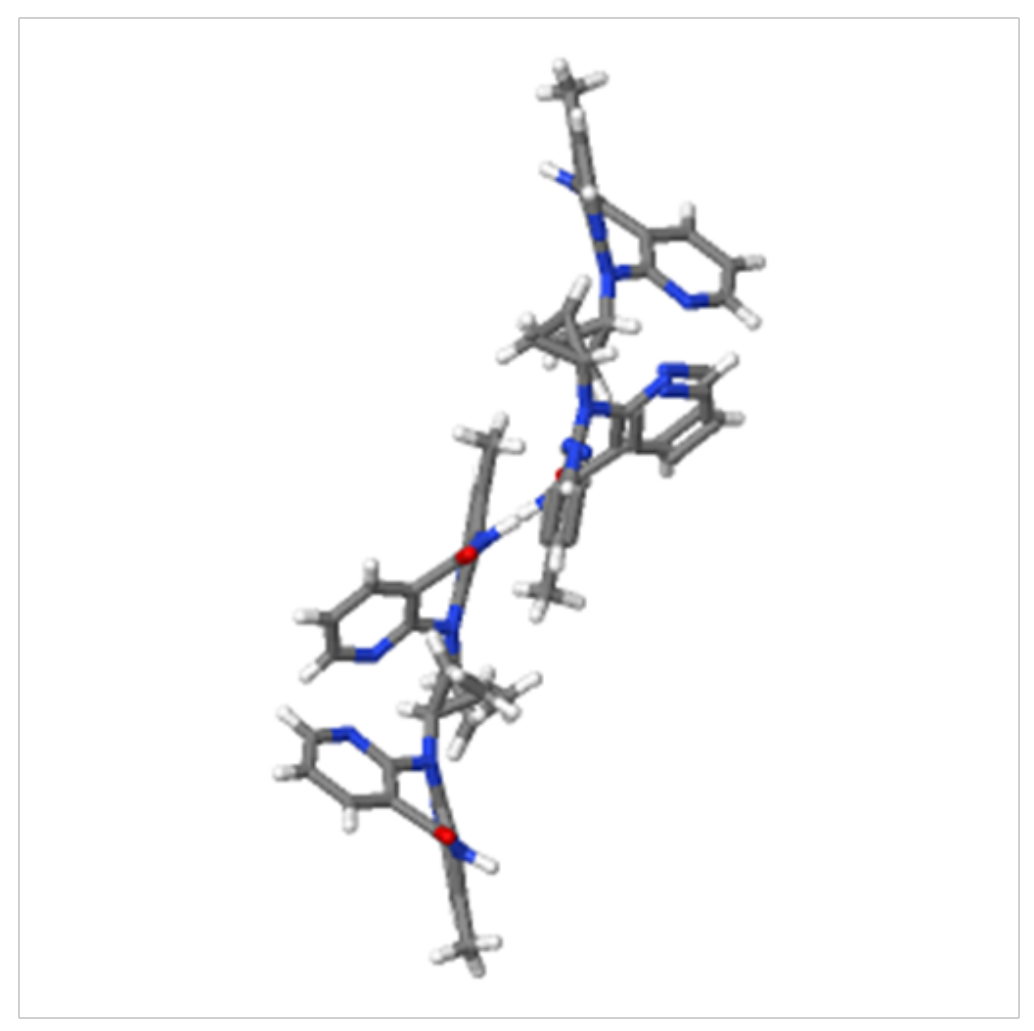

Figure 3 Crystal structure of NNRTIs Nevirapine $\left(\mathrm{C}_{15} \mathrm{H}_{14} \mathrm{~N}_{4} \mathrm{O}\right)$ an uncompetitive inhibitor. ${ }^{12}$ 
Mixed and non-competitive inhibition: Mixed inhibition is a combination of two type of inhibition competitive and uncompetitive.
Mixed inhibitor can bind both enzyme and enzyme substrate complex (Table 1). ${ }^{12-14}$

Table I a) The three major forms of reversible enzyme inhibition; (b) cartoon representations of the mechanisms for the reversible inhibition of enzyme catalysis. E, enzyme; S, substrate; P, product; I, inhibitor; ES, enzyme-substrate complex; El, enzyme-inhibitor complex; ESI, enzyme-substrate-inhibitor complex (c) Linweaver-Burk plots for competitive inhibition, noncompetitive inhibition, and uncompetitive inhibition; (d) effect of inhibition on Michaelis constant ( $\mathrm{K}_{\mathrm{M}}$ ) and maximum velocity $\left(\mathrm{V}_{\max }\right)$ of the enzyme. ${ }^{13-14}$

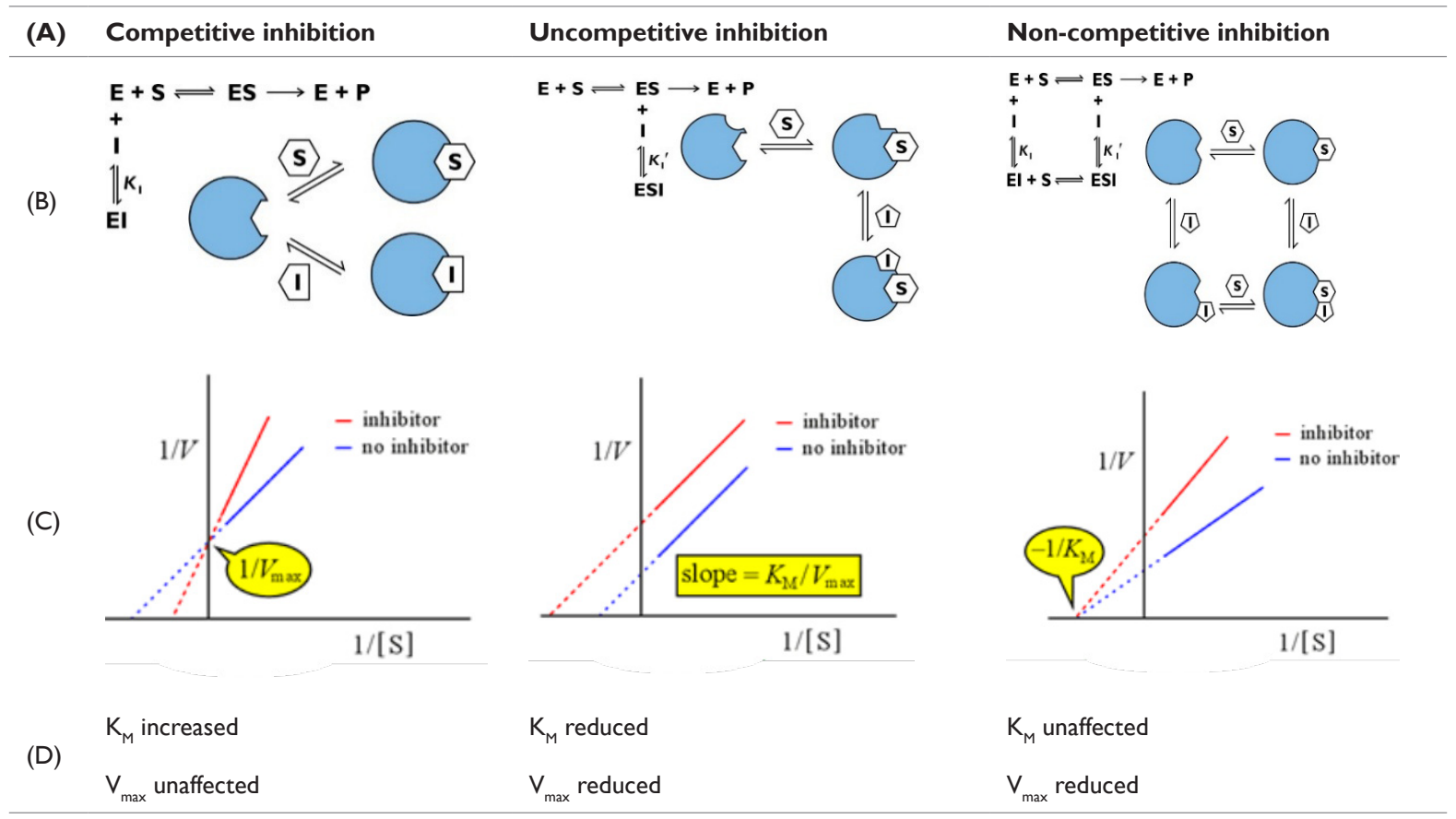

\section{Irreversible inhibition}

The irreversible inhibitors merge covalently with or affect a useful group on an enzyme that is essential for the enzyme's activity or form a particularly stable non-covalent association. ${ }^{15}$ Irreversible inhibitors are subdivided into two groups; active site directed and suicide inhibition.

A suicide irreversible inhibitor is a molecule that is structurally like the substrate and binds in the active site in the same way as the substrate(s) binds. The inhibitor has a functional group, usually a leaving group, that is replaced by a nucleophile in the enzyme active site. When the enzyme acts on it like it were a substrate, it gets converted into a reactive molecule and then reacts with the active site forming a covalent bond and inhibiting the enzyme. This reaction with the suicide inhibitor removes active enzyme from the system. ${ }^{13}$ Diftuoromethylornithine (DFMO) is a specific irreversible inhibitor of ornithine decarboxylase. It plays an important role in controlling metastases. When injected to mice it ensures the reduction in the number of pulmonary tumors. DFMO exerts anti-neoplastic effects by "suicide enzyme inhibition" and is therefore specifically directed at tumor cells which have only limited enzymatic pathways for polyamine biosynthesis crucial for their growth. ${ }^{16}$

\section{Therapeutic use of enzyme inhibitors}

As illustrated in Table 2, enzymes take part in a wide range of human diseases, and many specific enzyme inhibitors have been developed to combat their activities, thus acting as therapeutic agents.

Table 2 Selected enzymes inhibitors and their pharmaceutical applications..$^{13,14}$

\begin{tabular}{lllr}
\hline Type of enzyme inhibitor & Enzyme inhibitor (drug) & Enzyme Target & Pharmaceutical use \\
\hline & Aspirin & Cyclooxygenase & Inflammation/pain/fever \\
& Penicillin & Transpeptidase & Bacterial infection \\
Irreversible inhibitors & Acyclovir & Viral DNA polymerase & Gout
\end{tabular}




\begin{tabular}{|c|c|c|c|}
\hline Type of enzyme inhibitor & Enzyme inhibitor (drug) & Enzyme Target & Pharmaceutical use \\
\hline \multirow{7}{*}{$\begin{array}{l}\text { Competitive reversible } \\
\text { inhibitors }\end{array}$} & $\begin{array}{l}\text { Lovastatin, Pravastatin, other } \\
\text { statins }\end{array}$ & HMG-CoA reductase & Cholesterol lowering \\
\hline & Captopril, enalapril & Angiotensin converting enzyme & Hypertension \\
\hline & Saquinavir, indinavir, ritonavir & HIV protease & AIDS \\
\hline & Acetazolamide & Carbonic anhydrase & Glaucoma \\
\hline & Viagra, Levitra & Phosphodiesterase & Erectile dysfunction \\
\hline & Gleevec & Bcr-Abl kinase & Cancer \\
\hline & Methotrexate & Dihydrofolate reductase & Cancer, bacterial infection \\
\hline \multirow{7}{*}{$\begin{array}{l}\text { Non competitive reversible } \\
\text { inhibitors }\end{array}$} & Nevirapine, efavirenz & HIV reverse transcriptase & AIDS \\
\hline & SB-715992 & KSP kinesin & Cancer \\
\hline & PD032590I, Cl- 1040 & MAP kinase kinase (MEK) & Cancer \\
\hline & TF-505 & Steroid 5a-reductase & Benign prostate Hyperplasia \\
\hline & Etoposide & Topoisomerase II & Cancer \\
\hline & Tacrine & Acetylcholinesterase & Alzheimer's disease \\
\hline & Trazodone & Adenosine deaminase & Depression \\
\hline \multirow{5}{*}{$\begin{array}{l}\text { Uncompetitive reversible } \\
\text { inhibitors }\end{array}$} & Mycophenolic acid,VX-I48 & $\begin{array}{l}\text { Inosine 5'-monophosphate } \\
\text { dehydrogenase }\end{array}$ & Immunosuppression, cancer \\
\hline & $\begin{array}{l}\text { Finasteride, epristeride, } \\
\text { dutasteride }\end{array}$ & Steroid $5 \alpha$-reductase & $\begin{array}{l}\text { Benign prostate hyperplasia, } \\
\text { male } \\
\text { pattern baldness }\end{array}$ \\
\hline & Valproic acid & UDP-glucuronosyltransferases & Xenobiotic metabolism \\
\hline & Camptothecin & Topoisomerase I & Cancer \\
\hline & Ciglitazone & $\begin{array}{l}\text { I5-Hydroxyprostaglandin, } \\
\text { Dehydrogenase }\end{array}$ & Inflammatory diseases \\
\hline
\end{tabular}

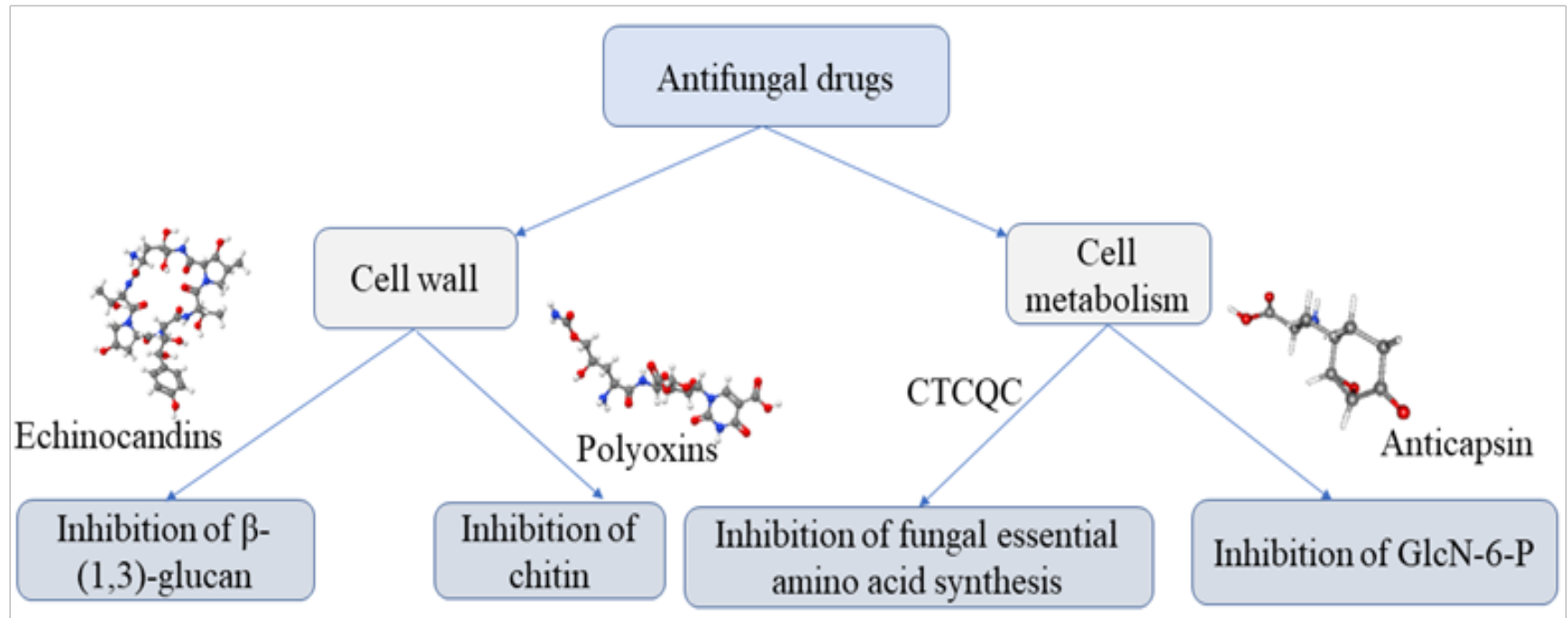

Figure 4 Pathways of fungal inhibition by enzyme inhibitor. ${ }^{20-22}$ 


\section{Antifungal drugs}

Echinocandins, enfumafungin and, papulacandins are enzyme inhibitors with potent antifungal activity. They act as inhibitors of the biosynthesis of $\beta$-(1,3)-glucan, the major components of the cell wall of various fungi. ${ }^{17}$ Polyoxins and nikkomycins are competitive inhibitors homologue to UDP-N-acetyl glucosamine a substrate for chitin synthesis. Both enzymes inhibitors alter the chitin synthesis and consequently play an important role in antifungal therapy (Figure 4). ${ }^{17}$ Several enzyme inhibitors affect the cell metabolism fungal. Some inhibitors affect the biosynthesis of amino acid pathway such as 6-carbamoyl-3a,4,5,9 tetrahydro-3H-cyclopenta [c]quinoline-4carboxylic acid (CTCQC) that reduce the virulence factor and have growth defects. Whereas, other inhibitors affect the biosynthesis of Glucosamine-6-phosphate synthase (GlcN-6-P) that catalyzes the transfer of an amino group from L-glutamine to D-fructose6-phosphate with the formation of D-glucosamine-6-phosphate. The resultant D-glucosamine-6-phosphate is the substrate for the synthesis of macromolecules containing chitin and mannoproteins. ${ }^{17}$ The GlcN-6-P inhibitors are a glutamine analog, that act as an activesite-directed inactivator, blocking the $\mathrm{N}$-terminal, a glutamine binding domain of the enzyme, for example N3-(4-methoxyfumaroyl)-L-2,3diaminopropanoic acid (FMDP), anticapsin are GlcN-6-P inhibitors. ${ }^{18}$ The interaction between FMDP and GlcN-6-P synthase was well studied by Wojciechowski demonstrate that the amino acids Asp123, His97 and Thr76, serves as the "anchor" mostly responsible for keeping the inhibitor in the binding pocket in addition to several strong and stable hydrogen bonds formed between the amid moiety of the inhibitor and the Gly99 and Thr76 residues present in the binding site (Figure 5). ${ }^{19}$

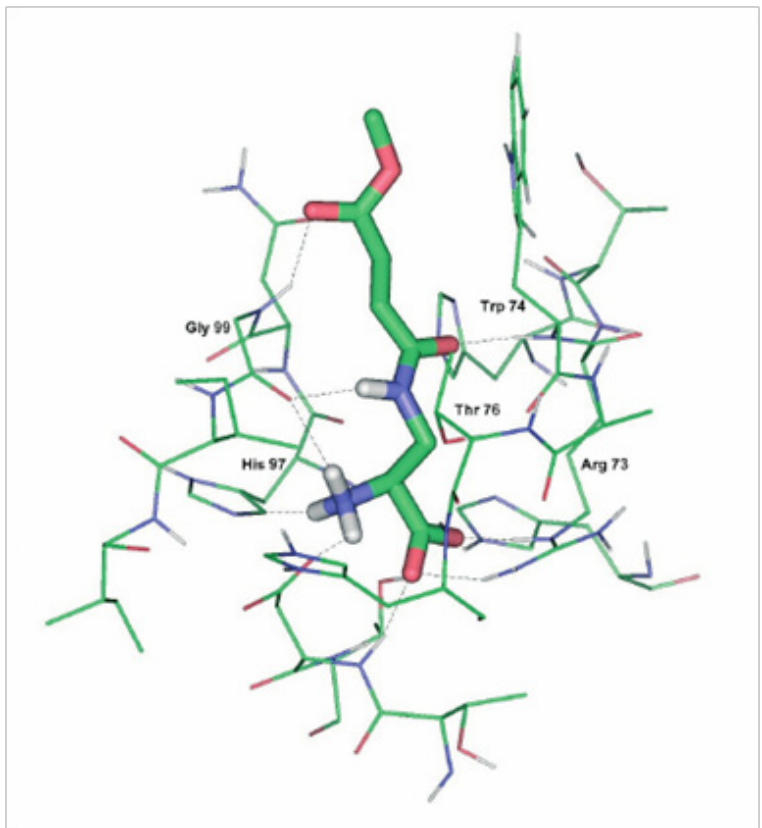

Figure 5 Molecular docking showing interaction of FMDP inside the glutamine-binding site of GlcN-6-P synthase. ${ }^{18}$

\section{Cancer therapies drugs}

The initiation and progress of human cancer is associated with kinase. The development of protein kinase inhibitors has proven successful in clinical treatment of various types of cancer. ${ }^{20-23}$ Imatinib and dasatinib, kinase inhibitors have proved a significant increase in patient survival incidence in myeloid leukemia (CML) and gastrointestinal stromal tumors (GIST). They are approved by the FDA. Structural analysis, molecular docking and magnetic resonance spectroscopy ensured the development of specific and robust kinase inhibitors ${ }^{24}$ such as nilotinib, approved for imatinib-resistant CML and with a selectivity profile like imatinib. ${ }^{25}$

\section{Enzyme inhibitors and human disease disorders treatment}

Enzyme inhibitors are also widely used.in cardiovascular disease. ${ }^{26}$ Tofacitinib, a JAK 3 inhibitor, was approved for treatment of rheumatoid arthritis in 2012. ${ }^{27}$ Several enzymes are used to control hypertension such as Angiotensin-converting enzyme inhibitors and renin inhibitors. ${ }^{28}$ A significant number of antibiotics are also enzymes inhibitors such as penicillin an irreversible suicidal inhibitor $\beta$-lactams, macrolides, ketolides and pleuromutilins. ${ }^{29}$ The control of thyroidal disorder is also largely based on enzyme inhibition to control the overproduction of THs by thyroid gland. ${ }^{30}$

\section{Conclusion}

The enzyme catalytic power fuels all metabolic processes of life, making biocatalysts attractive targets for therapeutic uses in aberrant human metabolism or in pathogenic metabolism associated with infectious microorganisms. Recent advances in structural biology and drug design provide ample opportunities to attack enzyme targets from a structural, or rational, basis. These combined with biochemical and mechanistic enzymological data provide a potent mechanism for inhibitor discovery. Moreover, advances in catalomics and enzymome high-throughput screening microarray technologies during the last decade added to the armament of tools for enzyme inhibitor discovery and optimization.

\section{Acknowledgments}

None.

\section{Conflicts of interest}

Author declares that there are no conflicts of interest.

\section{References}

1. Bruice TC, Benkovic SJ. Chemical basis for enzyme catalysis. Biochemistry. 2000;39(21):6267-6274.

2. John M Rimoldi. Book Review of Enzyme Inhibition in Drug Discovery and Development. The Good and the Bad. J Med Chem. 2010;53(11):4560-4560.

3. Allen Krantz. A Classification of Enzyme Inhibitors. Bioorganic \& Medicinal Chemistry Letters. 1992;2(11):1327-1334.

4. Ring B, Wrighton SA, Mohutsky M. Reversible mechanisms of enzyme inhibition and resulting clinical significance. Methods Mol Biol. 2014;1113:37-56.

5. Bhagavan N, Chung-Eun Ha. Enzyme and enzyme regulation in Essentials of Medical Biochemistry. $2^{\text {nd }}$ edn. Academic Press; 2015. 752 p.

6. Tan L, Su J, Wu D, et al. Kinetics and Mechanism Study of Competitive Inhibition of Jack-Bean Urease by Baicalin. The Scientific World Journal. 2013;1:879501.

7. Vega Hissi EG, Andrada MF, Zamarbide GN, et al. theoretical study of sulfanilamide and derivatives with antibacterial activity: conformational and electronic analysis. J Mol Model. 2011;17(6):1317-1323. 
8. Threlfall TL, Hursthouse MB, Coles SJ, et al. University of Southampton. Crystal Structure Report Archive. 1998.

9. Lain G, Dougall, John Unitt. Evaluation of the biological activity of compounds in the practice of medicinal chemistry. Academic Press; Fourth edition. 2015. 902 p.

10. Coster LO, Kumar PN. Contemporary role of Nevirapine in HIV treatment. AIDS Rev. 2012;14(2):132-144.

11. Michael S. The Nonnucleoside Reverse Transcriptase Inhibitors Efavirenz and Nevirapine in the Treatment of HIV. HIV Clinical Trials. 2005;6(3):158-168.

12. Caira MR, Stieger N, Liebenberg W, et al. Solvent Inclusion by the AntiHIV Drug Nevirapine: X-Ray Structures and Thermal Decomposition of Representative Solvates. Cryst Growth Des. 2008;8(11):7-23.

13. Copeland RA. Enzymes: A Practical Introduction to Structure, Mechanism and Data Analysis. 2nd edition. USA: Wiley, Hoboken; 2000. 416 p.

14. Copeland RA, Anderson PS. Enzymes and Enzyme Inhibitors in Textbook of Drug Design and Discovery. $3^{\text {rd }}$ edn. In: P Krogsgaard-Larsen, Liljefors T, Madsen U, editors. New York: Taylor and Francis; 2001. p. 328-363.

15. Copeland RA. Evaluation of Enzyme Inhibitors in Drug Discovery: A Guide for Medicinal Chemists and Pharmacologists. USA: Wiley, Hoboken; 2005. 572 p.

16. Niederkorn JY, Sanborn GE, Gamelf JW. Suicide Enzyme Inhibition as a Chemotherapeutic Strategy for Controlling Metastases Derived From Intraocular Melanomas. Invest Ophthalmol Vis Sci.1987;28(11):18441850 .

17. Ramakrishnan J, Rathore SS, Raman T. Review on fungal enzyme inhibitors-potential drug targets to manage human fungal infections. RSC Advances. 2016;6(48):42387-42401

18. Wojciechowski M, Milewski S, Mazerski J, et al. Glucosamine-6phosphate synthase, a novel target for antifungal agents. Molecular modelling studies in drug design. Acta Biochimica Polonica. 2005;52(3):647-653

19. Smith RJ, Milewski S, Brown AJP, et al. Isolation and characterization of the GFA1 gene encoding the glutamine: fructose-6-phosphate amidotransferase of Candida albicans. J Bacteriol. 1996;178(8):2320 2327.
20. Eschenauer G, DePestel DD, Carver PL. Comparison of echinocandin antifungals. Ther Clin Risk Manag. 2007;3(1):71-97.

21. Polyoxin B. 19396-06-6. Pubchem. 2005.

22. Chmara H, Zähner H, Borowski E. Anticapsin, an active-site directed irreversible inhibitor of glucosamine-6-phosphate synthetase from Escherichia coli. J Antibiot (Tokyo).1984;37(9):1038-1043.

23. Khushwant S Bhullar, Naiara Orrego Lagarón, Eileen M McGowan, et al. Kinase-targeted cancer therapies: progress, challenges and future directions. Mol Cancer. 2018;17(1):48-58.

24. Shukla S, Chufan E, Singh S, et al. Elucidation of the structural basis of interaction of the BCR-ABL kinase inhibitor, nilotinib (Tasigna) with the human ABC drug transporter P-glycoprotein. Leukemia. 2014;28(4):961964.

25. Steinberg M. Dasatinib: a tyrosine kinase inhibitor for the treatment of chronic myelogenous leukemia and philadelphia chromosome-positive acute lymphoblastic leukemia. Clin Ther. 2007;29(11):2289-2308.

26. Shahin R, Shaheen O, El-Dahiyat F, et al. Research advances in kinase enzymes and inhibitors for cardiovascular disease treatment. Future Sci OA. 2017;3(4):FSO204.

27. Roskoski R. USFDA approved protein kinase inhibitors. Pharmacol Res. 2015;144:19-50.

28. Kher V. Renin inhibition- benefit beyond hypertension control. J Assoc Physicians India. 2009;57:518-520.

29. Zhang Y, Sun j, Zhang J, et al. Enzyme inhibitor antibiotics and antibiotics associated diarrhea in critically III patients. Med Sci Monit. 2018;24:8781-8788

30. Mondal S, Mugesh G. Novel thyroid hormone analogues, enzyme inhibitors and mimetics, and their action. Mol Cell Endocrinol. 2017;458(15):91-104. 